\title{
BIOCHEMICAL AND PHYSIOLOGICAL EFFECTS OF MELATONIN, VITAMIN E + SELENIUM ON HEART, LUNG AND KIDNEY ANTIOXIDANT ENZYMES OF MALE AGING RATS.
}

\author{
Mohammed K. M. Mahfouz'; Afaf D. Abd El-Magied; Hussein A. A. Abdel- \\ Maksoud'; Yakout A. Y. El-Senosi' and Randa, S. $A^{2}{ }^{2}$ \\ 'Dep. of biochemistry fac. of. Vet. Med (Moshtohor) Zagazig university-Benha Dranch \\ ${ }^{2}$ Dep. of physiology fac. of vet. Med (Moshtohor) Zagazig university-Benha branch
}

\section{ABSTRACT}

Free radicals are one of the potential major causes of age related destruction. They are defined as any atom or molecule that possesse one or more unpaired electron. Antioxidants such as vitamin E+ Selenium and melatonin are substances that prevent deterioration damage caused by free radicals. They have been used in prophylaxis and treatment of various diseases affect elderly persons include cancer, cardiac diseases multiple sclerosis and arthritis. In this study 48 male albino rats were kept at constant environmental and nutritional conditions, then classified into 4 equal groups.

Group I used as control young (2-4 months old) not supplied by any additives, group II control aging (12-27 months old) not supplied by any additives, group III aged male rats administered by melatonin at a dose $0.27 \mathrm{mg} / \mathrm{kg}$ body weight daily for three months orally, and group IV aged rats injected quickly by I.M route with vitamin E+ Selenium $20 \mathrm{mg} / \mathrm{kg}$ body weight and $0.15 \mathrm{mg} / \mathrm{k}$. gm. b. w, respectively for three months. After 12 weeks from the onset of administration the rats were killed by decapitation.The heart, lung and kidney were rapidly removed, washed with saline and processed directly for determination of superoxide dismutase activity (SOD), Glutathione peroxidase (GSHPX), catalase activity and Reduced glutathione (GSH). The obtained data revealed significant decrease in heart, lung and kidney (SOD) and (GSHPX) activities of aged male rates. A high significant increase in heart and lung (SOD), kidney (GSHPX) activities as well as significant increase in (GSHPX) of heart and lung in melatonin administered group. Moreover significant increase in heart and lung (SOD) and heart, kidney (GSHPX) of aged male rats treated with vitamin E+ selenium. After administration of melatonin, heart and lung catalase activity increased significantly while (GSH) concentration showed significant decrease in kidney of aged itoin administrated group, slgnifican increase in neart of vit. $\mathrm{E}+$ selenım injected group.

\section{UCTION}


Aging usually accompanied with a hypermetabolic state including alteration in antioxidant enzyme activities as SOD, GSHPX and catalase. Moreovers depleting cellular stores of antioxidant materials such as vitamin E and GSH (Thomas, 1994).

Age plays an outstanding role in the process of DNA damage, which may occur as a result of an imbalance between the production and removal of free radicals. Thus the highest incidence of cell associated with antioxidant concentration (Mendoza et al., 1999). Moreover Amira et al. (2000) showed that oxidative stress resulted in a significant reduction in kidney catalase activity whereas SOD and GSHPX as well as GSH content showed significant increase that indicate an intial compensatory response to oxidative stress. Since SOD has been proposed to be the first line of defense against superoxid mediated injury. Also ElBoghdady et al. (2002) noticed that there was a significant decrease in the activities of SOD, Glutathione reductase (GR) of aged male albino rats. These changes were attributed to the free radicals that produced during aging progress.

Melatonin is a very potent and efficient antioxidant. It confere protection against the oxidative damage through its indol structure which act as free radical scavenger. Hara et al. (1997), as well as induction of antioxidant enzymes as SOD, catalase and GSHPX via specific melatonin receptors (Pablos et al., 1997). Moreover, stimulation of gene expression for antioxidant enzymes as it increase the level of mRNA for GSHPX and SOD in tissue (Kotler et al., 1998) consequently melatonin have been used successfully in prophylaxis and treatment of various diseases especially those caused by free radicals such as disease affective elderly persons (Eldenshary, 1998).

Pablos et al. (1997) showed that damage in lung of rats induced by oxidative stress through increasing the activities of GSHPX and glutathione reductase GR while decrease GSH to be similar to those of control animals. They attributed this results to the ability of melatonin to scavenge free radicals as well as induction of antioxidative enzymes via specific melatonin receptors.

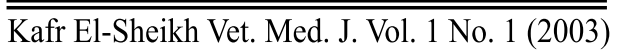


Abd El-Wahab et al. (1998) reported that, administration of melatonin significantly increased the cardiac level of GSH by $39 \%$ and SOD activity by $37 \%$ in Swiss albino mice.

Banks (1996) showed that vitamin E ameliorated the significant change on lipid peroxidase of heart plasma of male swine caused by aging.

Othman and El-Mesiri (1997) demonstrated that injection of selenium enhance the endogenous antioxidant capacity of cell by increasing the activity of SOD, GR and GSH content of kidney in male rats. Also Stajn et al. (1997) noted that selenium treatment was significantly increased kidney $\mathrm{Cu} / \mathrm{Zn}$ SOD whereas catalase and GSHPX activities were unchanged. Moreover Attia et al. (1998) reported that vitamin E treatment significantly ameliorated the low kidney content of GSH as well as SOD activity caused by stress in rats.

Manal and Soad (1999) showed that, administration of selenium significantly rise GSH content, GSHPX activity in heart, kidney and liver of adult male albino rats, contributed these results to the protective effect of selsnium on the antioxidant defense system. Thus it provide a significant improvment in elderly patient. Girodon et al. (1999).

Abd El-salam (2002) recorded that administration of selenium and vitamin $\mathrm{E}$ correct the change in SOD activity and glutathione content induceed by oxidative stress caused by irradiation. As well as Colitti et al. (2000) reported that, sheep receiving alpha tocopherol significantly increased GSHPX activity. Moreover, Milad et al. (2001) confirmed that, the synergism between vitamin $\mathrm{E}$ and selenium were significantly increased GSHPX concentration and catalase activity in blood Hala (2002).

\section{Aim of the work:-}

Accordingly, the present study was carried out to investigate the effect of aging, as well as melatonin and vitamin E+ selsnium on the level of heart, lung and kidney antioxidant enzyme activites such as glutathione proxidase (GSHPX), superoxide dismutase (SOD), and catalase in addition to reduced glutathione $(\mathrm{GSH})$ concentration of aging male rats. 


\section{MATERIALS \& METHODS}

The present study was carried out on total number of 48 male albino rats. All rats were kept at constant environmental and nutritional conditions, through the period of the experiment, fed with pelleted feed and water was supplied ad. libitum.

The animals were divided into four groups, 12 rats in each as follows:

Group I: control young (2-4 months old) not supplied by any additives.

GroupII:control aging (12-27 months old) not suppliedd by any additive.

GroupIII:Aged male rats supplemented with melation orally at a dose of $0.27 \mathrm{mg} / \mathrm{Kg}$ body weight daily for three months.

Group IV:Aged rats injected with vitamin $\mathrm{E}(\alpha$-tocopherol $)+$ selenium at a dose of $20 \mathrm{mg} / \mathrm{K} \mathrm{g}$. b. wt. and $0.15 \mathrm{mg} / \mathrm{K} \mathrm{g}$. b. wt, respectively every week by $\mathrm{I} / \mathrm{M}$ injection for three monthes.

The doses were calculated according to Pagget and Burnes (1964) soon after decapitation heart, lung and kidney were rapidly removed, washed with plysiological saline solution and homogenized directly by electric homogenizer on an ice cooled phosphate buffer $\mathrm{pH} 7.4$, then centrifuged at 3000r.p.m for $15 \mathrm{~min}$ at $4 C^{5}$ (Fahiem and Attia,1996). The supernatant obtained was used freshly for determination of the activities of Cu/Zn SON (Nebot,1993), catalase (Sinha,1972) and GSHPX (Avissar et al., 1991) on addition to GSH content (Beutler et al., 1963).

Statistical analysis of the data was performed using student t-test Kempthorn (1969).

\section{RESULTS}

Table (1) and Fig (1) revealed a significant decrease in heart, lung and kidney $\mathrm{Cu} / \mathrm{Zn}$ SOD activity of aged male rats compared with young control group. A high significant increase in heart and lung $\mathrm{Cu} / \mathrm{Zn}$ SOD activity on melatonin treated group of aged male rats. As well as significant increase in heart and lung $\mathrm{Cu} / \mathrm{Zn}$ SOD activity of aged male rats treated with Vit. E + Selenium compared with control aged group. 
Table (2) and Fig (2) showed significant decrease in heart, lung as well as high significant decrease, in kidney GSHPX activity of aged male rats compared with young control group. A high significant increase in kidney while significant increase in heart and lung GSHPX activity of aged male rats treated with melatonin. Moreover significant increase in heart and kidney GSHPX activity on Vit. E + Selenium treated group.

Table (3) and Fig (3) showed significant decrease in heart and kidney catalase activity while non significant changes were obtained in lung of aged male rats compared with young control group. There were a significant increase in heart, lung catalase activity in melatonin treated aged male rats, while non significant change in heart, lung and kidney catalase activity of aged male rats treated with Vit. E + Selenium.

Table (4) and Fig (4) revealad significant decrease in kidney while non significant change in heart and lung GSH content of aged male rats compared with young control group. Significant increase in heart and kidney GSH content of melatonin treated aged male rats. Moreover significant increase in heart while non significant changes in lung and kidney GSH content of aged male rats treated with Vit. E + Selenium.

Table(1):Effect of melatonin and vitamin E + selenium on SOD activity of heart, lung and kidney of aged male rats.

\begin{tabular}{||l||c|c|c||}
\hline \multicolumn{1}{|c||}{\multirow{2}{*}{ Groping }} & \multicolumn{2}{c|}{ Cu / Zn SOD $(\boldsymbol{\mu} / \mathrm{mg}$ protein) Mean \pm SE } \\
\cline { 2 - 4 } & Heart & Lung & Kidney \\
\hline \hline Control young (GI) & $20.00 \pm 2.31$ & $33.12 \pm 1.77$ & $11.35 \pm 2.05$ \\
\hline Control Aged (GII) & $12.99 \pm 1.02^{*}$ & $23.00 \pm 2.15^{*}$ & $5.59 \pm 0.81^{*}$ \\
\hline Melatonin (GIII) & $34.12 \pm 3.79^{* *}$ & $49.37 \pm 4.61 * *$ & $6.52 \pm 0.30$ \\
\hline Vitamin E + Selenium (GIV) & $19.11 \pm 1.85^{*}$ & $30.95 \pm 1.64 *$ & $7.88 \pm 0.75$ \\
\hline
\end{tabular}

$\overline{\overline{\text { Kafr El-Sheikh Vet. Med. J. Vol. } 1 \text { No. } 1 \text { (2003) }}}$ 
Table(2):Effect of melatonin and vitamin E + selenium on GSHPX activity of heart, lung and kidney of aged male rats.

\begin{tabular}{|l|c|c|c||}
\hline \multirow{2}{*}{ Groping } & \multicolumn{3}{c|}{ GSHPX $(\boldsymbol{\mu} / \mathbf{m g}$ protein) Mean \pm SE } \\
\cline { 2 - 4 } Control young (GI) & Heart & Lung & Kidney \\
\hline Control Aged (GII) & $43.11 \pm 3.16$ & $232.00 \pm 26.02$ & $167.70 \pm 10.30$ \\
\hline Melatonin (GIII) & $32.60 \pm 1.8^{*}$ & $129.13 \pm 10.23 *$ & $97.05 \pm 7.88^{* *}$ \\
\hline Vitamin E + Selenium (GIV) & $39.87 \pm 1.72 *$ & $202.61 \pm 19.69 *$ & $162.50 \pm 9.83 * *$ \\
\hline \multicolumn{3}{|c|}{$*$ Significant at $(P<0.05)$} & $* *$ Significant at $(P<0.01)$ \\
\hline
\end{tabular}

Table(3):Effect of melatonin and vitamin E + selenium on Catalase activity of heart, lung and kidney of aged male rats.

\begin{tabular}{||l||c|c|c||}
\hline \multicolumn{1}{|c||}{ Groping } & \multicolumn{3}{c|}{ Catalase $(\boldsymbol{\mu}$ /mg protein) Mean \pm SE } \\
\cline { 2 - 5 } & Heart & \multicolumn{1}{c|}{ Lung } & Kidney \\
\hline \hline Control young (GI) & $34.61 \pm 2.35$ & $22.50 \pm 2.17$ & $3.88 \pm 0.22$ \\
\hline Control Aged (GII) & $2.49 \pm 2.85 *$ & $20.00 \pm 1.22$ & $3.00 \pm 0.23 *$ \\
\hline Melatonin (GIII) & $33.50 \pm 1.99^{*}$ & $25.43 \pm 1.41 *$ & $3.50 \pm 0.86$ \\
\hline Vitamin E + Selenium (GIV) & $28.00 \pm 2.01$ & $21.25 \pm 1.67$ & $3.14 \pm 0.69$ \\
\hline
\end{tabular}

Table(4):Effect of melatonin and vitamin E + selenium on GSH activity of heart, lung and kidney of aged male rats.

\begin{tabular}{|l||c|c|c||}
\hline \multicolumn{1}{|c||}{ Groping } & \multicolumn{3}{c|}{ GSH $(\mu /$ mg protein) Mean \pm SE } \\
\cline { 2 - 4 } & Heart & Lung & Kidney \\
\hline \hline Control young (GI) & $9.81 \pm 1.02$ & $7.60 \pm 0.65$ & $12.75 \pm 1.16$ \\
\hline Control Aged (GII) & $7.09 \pm 0.43$ & $10.21 \pm 1.01$ & $8.80 \pm 0.59 *$ \\
\hline Melatonin (GIII) & $10.75 \pm 0.96^{*}$ & $8.00 \pm 0.87$ & $11.81 \pm 0.77^{*}$ \\
\hline Vitamin E + Selenium (GIV) & $9.79 \pm 0.81^{*}$ & $9.18 \pm 0.96$ & $9.90 \pm 0.68$ \\
\hline
\end{tabular}

* Significant at $(P<0.05)$

** Significant at $(P<0.01)$

$\overline{\overline{\text { Kafr El-Sheikh Vet. Med. J. Vol. } 1 \text { No. } 1 \text { (2003) }}}$ 


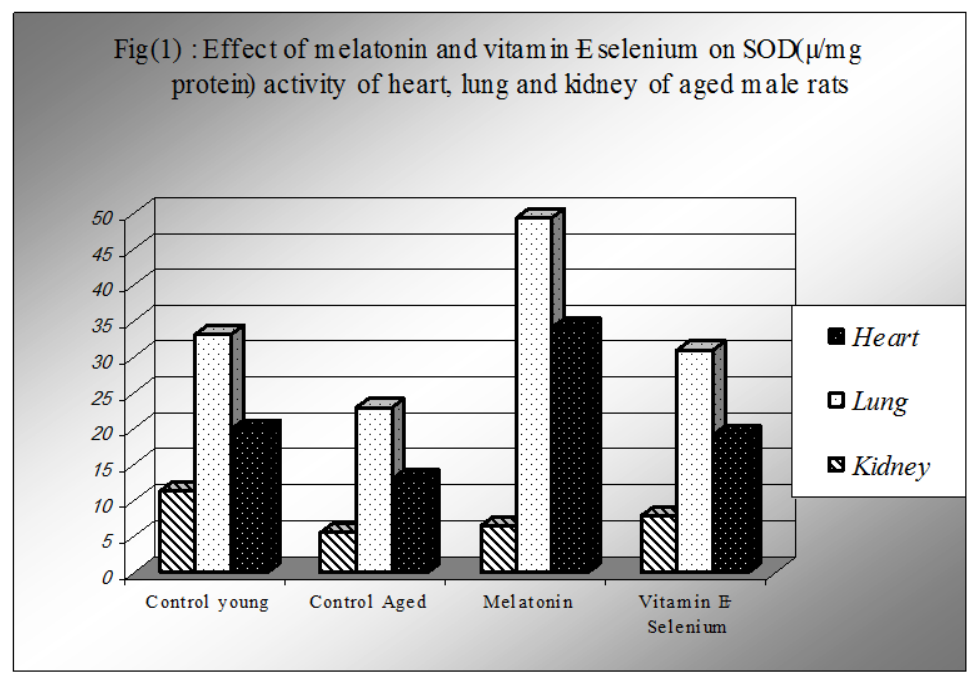

Fig(2) : Effect of melatonin and vitam in Eselenium on GSHPX ( $\mu / \mathrm{mg}$ protein) activity of heart, lung and kidney of aged male $\mathrm{r}$ :

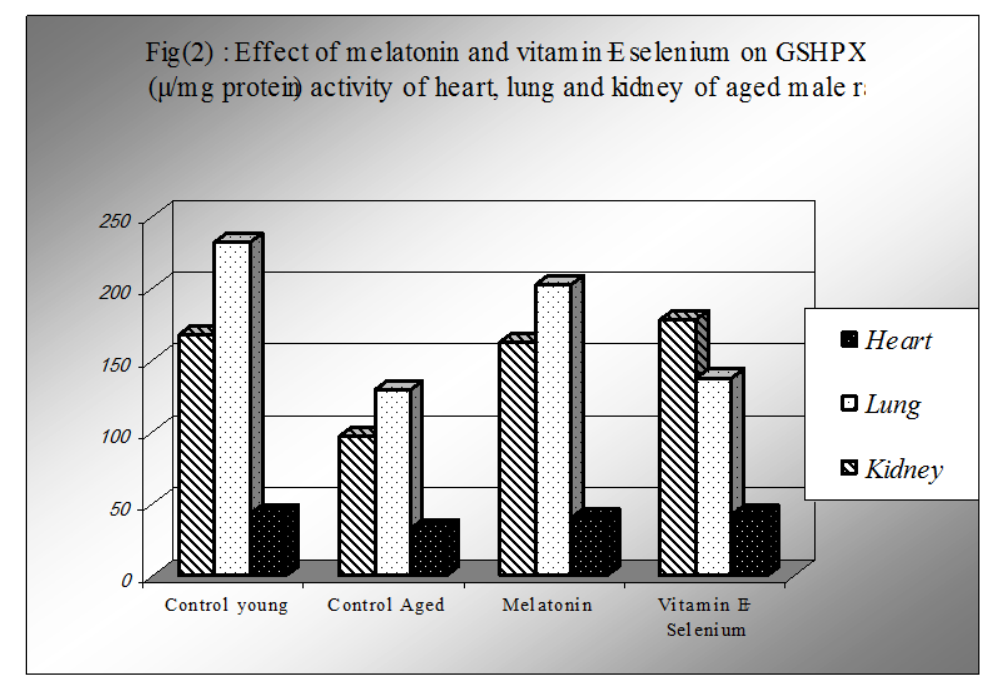

$\overline{\overline{\text { Kafr El-Sheikh Vet. Med. J. Vol. } 1 \text { No. } 1 \text { (2003) }}}$ 
Fig(3) : Effect of melatonin and vitam in E selenium on Catalase ( $\mu / \mathrm{mg}$ protein) activity of heart, lung and kidney of aged male $\mathrm{r}$

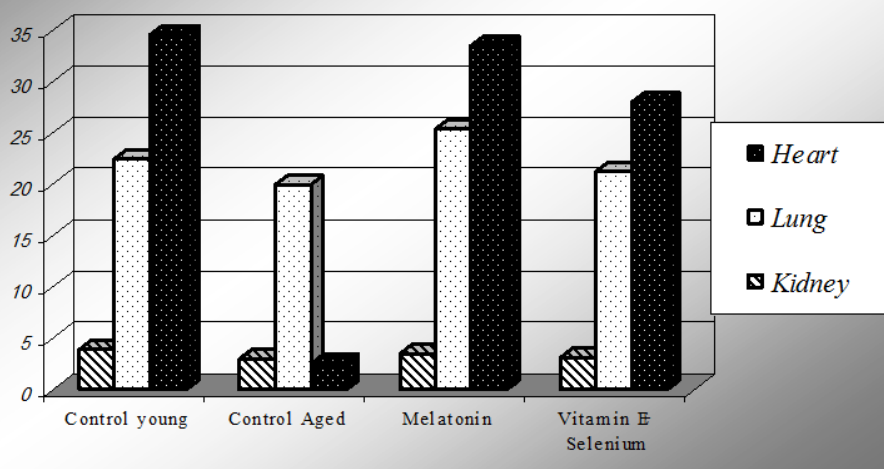

Fig(4) : Effect of melatonin and vitam in Eselenium on GSH $(\mu / \mathrm{mg}$ protein) activity of heart, lung and kidney of aged male rats

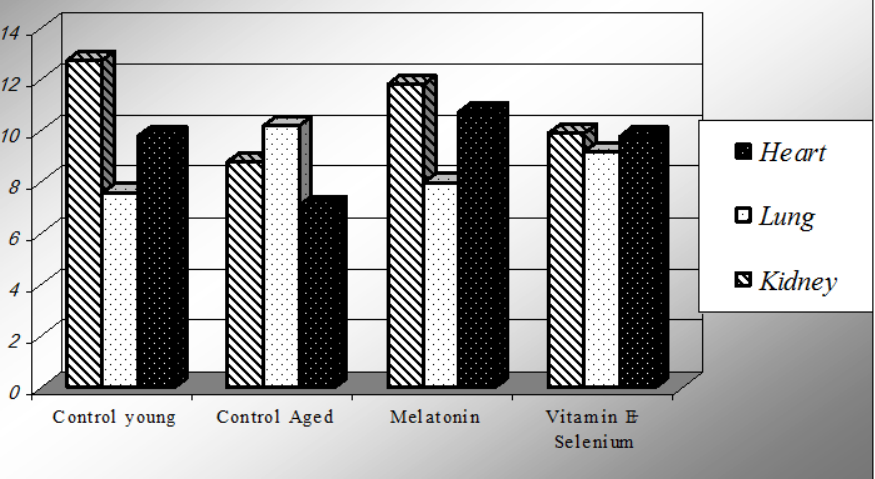

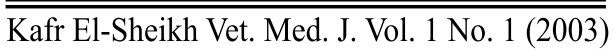




\section{DISCOSSION}

The recorded significant decrease in heart, lung kidney $\mathrm{Cu} / \mathrm{Zn}$ SOD and catalase activities of male rats by aging could be attributed to the reduction in protein synthesis and increase in protein degradation or both (Dillon et al. 1990). It might be also explained by taking the free radical theory of aging in consideration (El Boghdady et al. 2002) as those free radicals resulted in the formation of protein peroxide as well as inactivation of detoxifying enzyme such as GSHPX by splitting of the peptide chain (Pigeolet and Ramacele 1991) with respect the significant decline in kidney GSH concentration of aging male rats compared with young control group. It could be attributed to over production of free radicals leading to depletion of cellular stores of antioxidant (Manal and Soad 1999) such as reduction of glutathione reductase (GR) activity or extensive utilization of GSH in scavenging free radicals by allowing the hydrogen of SH group to be abstracted instead of unsaturated Fatty acid. (Fahim and Attia 1996)

Regarding the effect of melatonin administration our data were came in accordance to those reported by (Abd El-Wahab et al. 1998) who showed that melatonin significantly increased the cardiac SOD activity by $37 \%$ and GSH content by $39 \%$ in swiss albino mice as it is effective in protecting nuclear DNA through altering the activity of enzymes which improve the total antioxidative defense capacity such as SOD (Gilad et al. 1997) as well as induction of antioxidant enzymes as SOD, catalase and GSHPX via specific melatonin receptors. Moreover melatonin prevent oxidative damage in lung of rats induced by oxidative stress through increasing the activities of GSHPX and GR (Pablos $\boldsymbol{e t}$ al. 1997) which are necessary for conversion of GSSG to GSH. As GR posses a critical sulphhydryl group at its active site which participate in the reduction of oxidized glutathion (Othman and El Mesiri 1997).

Concerning the effect of Vit.E+Selenium our data was in agreement with those obtained by (Turan et al. 1997) who found that cardiac GSH content and GSHPX activity were significantly increased with Vit. E and selenium administration. Moreover a high significant increase in cardiac and renal GSHPX activity were recorded in stressed adult male rats by selenium treatment (Manal and soad 1999).

$\overline{\text { Kafr El-Sheikh Vet. Med. J. Vol. } 1 \text { No. } 1 \text { (2003) }}$ 
This results could be attributed to the protective effect of selenium on the antioxidant defense system as it acts as cofactor for GSHPX which is cytoprotective enzyme and so enhance the endogenous antioxidant capacity through increasing the activity of renal GR, SOD and GSH content (Othman and El Mesiri 1997). As well as vitamin E has been reported to be scavenger of oxygen free radicals which initiate and propagate chain oxidation, thus the synergism between Vit. E and selenium were signnificantly increased GSHPX activity (Milad et al. 2001) and catalase activity (Hala 2002). Also correct the change in SOD activity and glutathione content induced by oxidative stress (Abd $\boldsymbol{E l}$ salam 2002).

\section{REFERENCE}

- Abd El-Salam (2002):"Role of selenium as antioxidant on some Biochemical Alteration induced by Gamma irradiation on male rats". The $5^{\text {th }}$ National Conference of Biochem. and Molecular, Biology May 12-14.

- Abd El-Wahab ,M.H .; Akoul, S.E and Hamada,F.M (1998): Mitigaration of doxorubcin-induced cardiotoxicity by melatonin.The Egypt.Soci. Toxicol . April 1-3.

- Amira A. Shaheen, Adel A. Kheir-Eldin, Amal A. Abd El-Fattah and Hebatallah A. Darwish (2000): "Effect of Some Food Additive on Oxygen- Scavenger System in Young Male Rats" The Egyptian J.of Biochem. 18 (2).

- Attia, F. F; Abd El-Wahab, H.M; Abd El-Naim, A.B; and Rady, M.T. (1998): "Potential Protective Effects of Vit. E and/or Probucol Against Gentamicin Induced Nephrotoxicity."The Egypt. Soci: Toxicol April 1-3.

- Avissar ,J .; Sellemon ,R . and Cohen ,H . (1991): J . Nut. 121 ; 1243-49.

- Banks, M. A.;Berlin, E.; Jonson. A. and Peter, S. (1996): Vitamin $E$ levels and successptability to lipid peroxidation increase with aging in swine. J. Gerontol. A. Biol. Sci Med. Sci 51 (6) : 409.

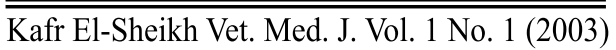


- Beutler, E.; Duran, O. and Kelly, B. (1963): Improved method for the determination of blood glutathione. J. of lab. and Clinc. Med. 61 : 882 .

- Colitti, M; Standaioli,G; and Stafanon,B.(2000):Effect of alphatocopherol depriviations on the involution of mamary gli sheep. J. Dairy-Sci., 83: 2, 345-50.

- Dillon, D.; Ji. L. L. and Wu, E. (1990): Alteration of antioxidant enzymes with aging in rat skeletal muscle and liver. Am. Physicol. Soci. 11:918-23.

- El-Boghdady N. A; Fahim A. T; and Barakat M. M; (2002): "Aging and Antioxidant Systems in Experimental Animals"The $5^{\text {th }}$ National Conference of Biochem. and Molecular Biology May 12-14.

- El-Denshary, E. S. (1998): Pharmacopreventive and pharmacotherapeutic significance of free radicals scavengers. The anual scientific conference. April 1-3,1998 Department of Pharmacology, Fac. of Pharmacy Cairo Univ.

- Fahim, A. T. and Attia, A. S. (1996): Effect of melatonin with vitamin E on lipid peroxidation in rat brain. Bull. Of Fac. Pharm. Cairo Univ. 34: 5-10.

- Gilad, E.; Salzman, A. and Szabo, C. (1997): Melatonin as a scavenger of peroxyl nitrate. Life. Sci. 60 (10): 169-74.

- Girodon, F.; Galan, P.; Monget, A. L. and Herchberg, S. (1999) :Impact of trace elements and vitamin supplementation on immunity and infection in eldery patients.Arch. Intern. Med. 12. 159 (7): 748-54.

- Hala, M; W; Saleh (2002):Biochemical influence of some additive on Ewes and newborn lambs. M.V. SC. Thesis Biochemistry Fac. Vet. Med. Zagazig Univ.

- Hara, M.; Iigo, M. and Reiter, R. J. (1997): Adminstration of melatonin and related indoles prevent exercise induced celluller damage in rats. Biolo. Signals. 6 (2): 90-100.

- Kempthorn, O. (1969): The design and analysis of expriments.In "John and Sonsion" New York, 47-96.

- Kotler, M.; Rodriguere, C.; Antolin, I. And Plaez, A. (1998) : Melatonin increases gene expression for antioxidant enzymes in rat brain cortex. J. Pineal. Res. 24 (2) : 83-9. 
- Manal, A. M. and Soad, H. A. (1999) : The protective effect of selenium on cadmium induced lipid peroxidation in rats. Egypt.J.of Biochem.17(1):1-20.

- Mendoza, V. M.; Retana, U. R. and Lozano, M. A. (1999): DNA damage

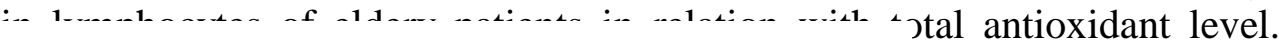

- Milad, K; Racz, O; Sipulova, A., Bajov V. and Kovac, G. (2001): Effect of vitamin $\mathrm{E}$ and selenium on blood glutathione peroxidase activity and some immunological parameters in sheep. Vet. Med., 46:1, 1-5.

- Nebot. C. (1993): Spectrophotometric Assay of SOD. activity based on the activated outooxidation of tetracyclic catechol. Analytical Biochemistry. 214: 442-451.

- Othman, A. I.; and El - Mesiri, M. A. (1997): Prophylactic role of selenium against lead toxicity in male rats. J. Union of Arab Biologists zoology. 7: 287-302.

- Pablos, M. I.; Reiter, R. J. and Deneke, S. M. (1997):Acutely adminstrated melatonin reduces oxidative damage in lung and brain induced by hyperbaric oxygen. J. Appl. Physiol. 83 (2): 354-8.

- Pagget and Burnes,R.(1964):Evaluation of drug activities. Vol.1 Academic press.

- Pigeolet,E.and Ramacele,L.(1991):Susceptabitity of glutathione peroxidase to proteolysis after oxidative alteration by peroxidase and hydroxyl radicals. Free. Radic. Biol. Med. 11: 191-95.

- Sinha, A. K.(1972): Colorimetric assay of catalase. Analytical Biochemistry 47:389.

- Stajn, A.; Zikic, R. V. and Petrovic, V. M. (1997): Effect of cadmium and selenium on the antioxidant defence system in rat kidneys Biochem. Physiol. 117 (2): 167-72.

- Thomas, J. A. (1994):IN “Modern nutrition in health and disease" P.501 ed. Philadelphia, Baltimor, Hong. Kong.

- Turan, B.;Nezahat, Z. and Nuri, A.(1997): Dietary selenium and vitamin E induced alteration in some rabbit tissues.Biol.Trace.Element.Res.58:237-53.

$\overline{\text { Kafr El-Sheikh Vet. Med. J. Vol. } 1 \text { No. } 1 \text { (2003) }}$ 
التأثير ات البيو كيميائية و الفسيولوجية للميلاتونين وفيتامين هـ + سيلنيوم على الإنزيمات

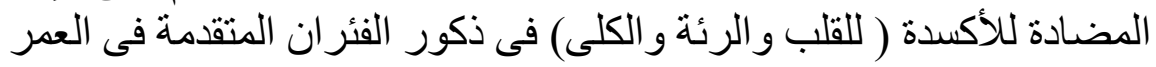

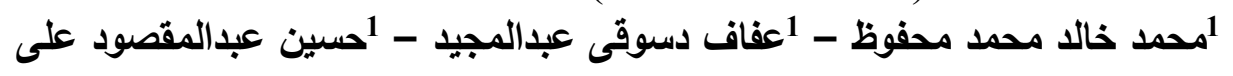

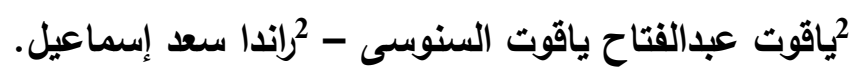

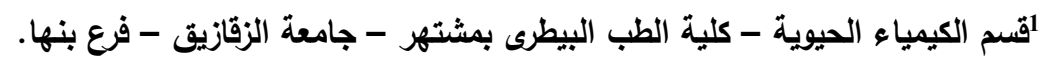

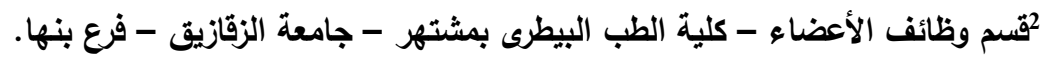

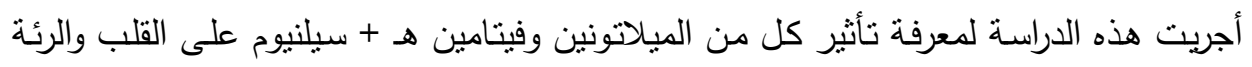

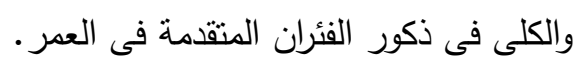

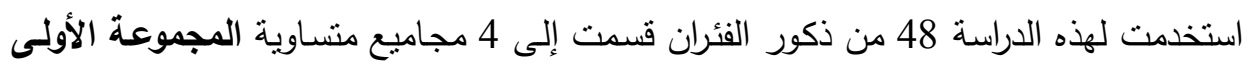

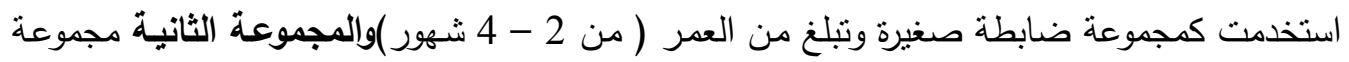

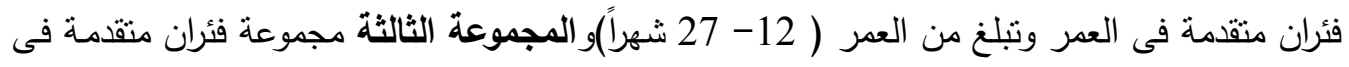

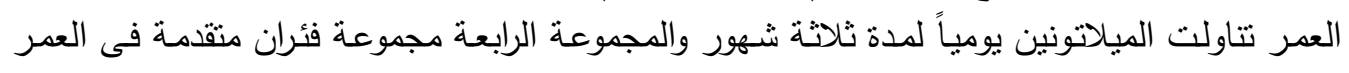

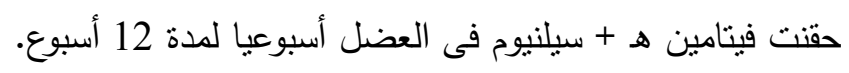

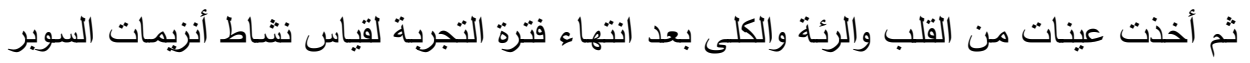

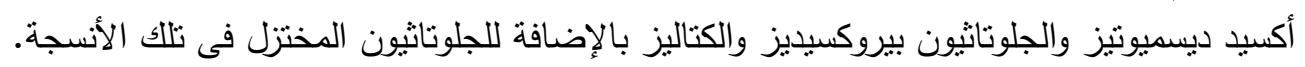

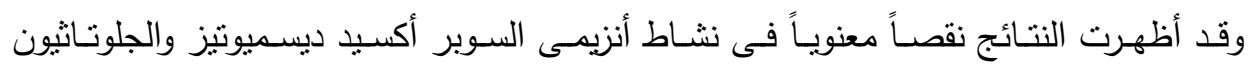

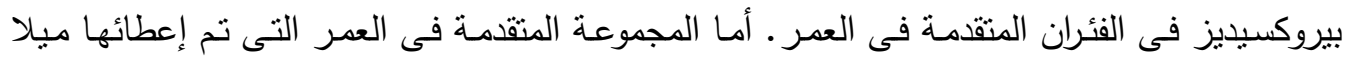

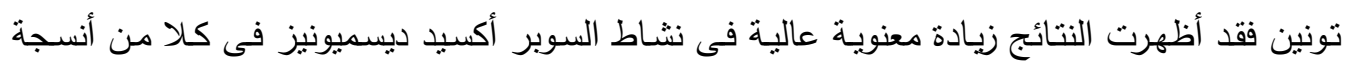

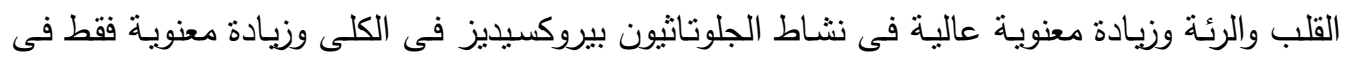

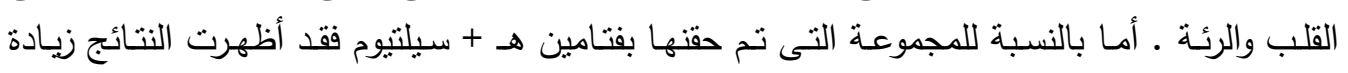

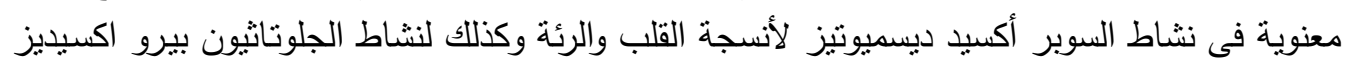
لأنسجة القلب والكلى.

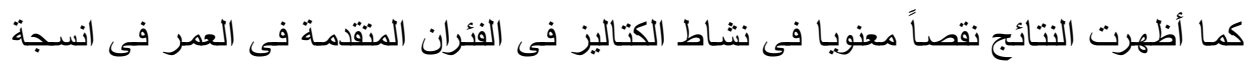

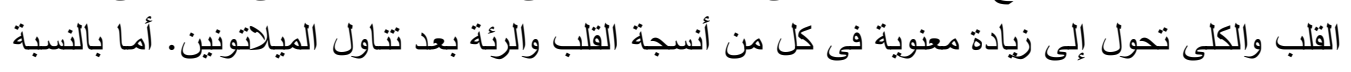

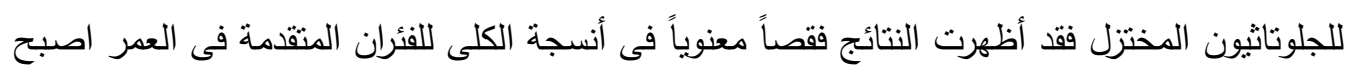

$\overline{\overline{\text { Kafr El-Sheikh Vet. Med. J. Vol. } 1 \text { No. } 1 \text { (2003) }}}$ 
زيادة معنوية فى أنسجة القلب والكلى فى المجموعة المتقدمة فى العمر النى نم إعطائها الميلاتونين وكذلك زيادة معنوية فى أنسجة القلب والكلى فى المجموعة التى تم حقنها بالفيتامين هـ + سيلنيوم.

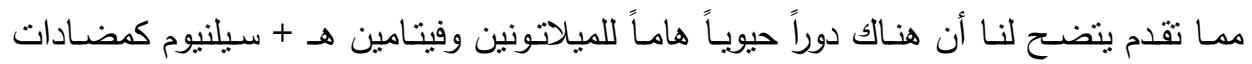

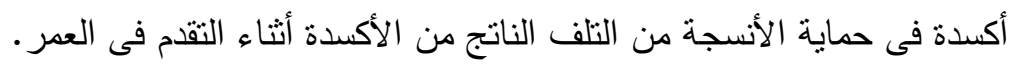

